\title{
Eggshell and Bacterial Cellulose Composite Membrane as Absorbent Material in Active Packaging
}

\author{
S. Ummartyotin, ${ }^{1,2}$ P. Pisitsak, ${ }^{3}$ and C. Pechyen ${ }^{1,2}$ \\ ${ }^{1}$ Advanced Functional Polymeric Materials Research Group, Faculty of Science and Technology, Thammasat University, \\ Patum Thani 12120, Thailand \\ ${ }^{2}$ Materials Research Center, HORIBA Scientific and Thammasat University, Patum Thani 12120, Thailand \\ ${ }^{3}$ Department of Textile Science and Technology, Faculty of Science and Technology, Thammasat University, \\ Patum Thani 12120, Thailand \\ Correspondence should be addressed to S. Ummartyotin; sarute.ummartyotin@gmail.com \\ and C. Pechyen; chiravoot.p@gmail.com
}

Received 3 April 2016; Accepted 16 May 2016

Academic Editor: Ming-Guo Ma

Copyright (C) 2016 S. Ummartyotin et al. This is an open access article distributed under the Creative Commons Attribution License, which permits unrestricted use, distribution, and reproduction in any medium, provided the original work is properly cited.

\begin{abstract}
Bacterial cellulose and eggshell composite was successfully developed. Eggshell was mixed with bacterial cellulose suspension and it was casted as a composite film. $\mathrm{CaCO}_{3}$ derived from eggshell was compared with its commercial availability. It can be noted that good dispersion of eggshell particle was prepared. Eggshell particle was irregular in shape with a variation in size. It existed in bacterial cellulose network. Characterization on composite was focused on thermal and mechanical properties. It showed that flexibility and thermal stability of composite were enhanced. No significant effect of mechanical properties was therefore observed. The thermal stability of composite was stable up to $300^{\circ} \mathrm{C}$. The adsorption experiment on water and vegetable oil capacity was performed. The enhancement on adsorption was due to the existence of eggshell in bacterial cellulose composite. It exhibited the potential to be a good candidate for absorbent material in active packaging.
\end{abstract}

\section{Introduction}

In recent years, the push on development on bio-based materials has been evident. Numerous efforts have been extensively developed in many types of bio-based products such as cellulose and derivatives, chitin and chitosan based materials, polylactic acid, polybutylene succinate, and starch as well as soy protein [1-3]. The role of bio-based materials can be employed in many sectors of application such as infrastructure, automotive part, and electronic device as well as active packaging [4-6]. One of the most effective bio-based materials was focused on cellulose [7-9]. From the fundamental point of view, it was remarkable to note that cellulose was considered as the most abundant naturally occurring biopolymer. It was commonly found in the cell walls of plant and certain algae. Cellulose derived from plant presented the excellence in terms of cost effectiveness, safety, and availability of raw materials. However, cellulose derived from bacterial specie presented the good effectiveness on purity and homogeneity [10]. The most effective specie was focused on Acetobacter xylinum. It presented the low coefficient of thermal expansion and also it was an outstanding reinforcing agent for the design of environmentally friendly composites. It is renewable and biodegradable. Young's modulus of its single fibril was measured to be as high as $114 \mathrm{GPa}$. It also has attractive features of high degree of crystallinity, high degree of polymerization $(14,400)$, and high specific area $\left(37 \mathrm{~m}^{2} / \mathrm{g}\right)$ [11-13]. From the past, our research group was focused on the development of bacterial cellulose and the study of its application $[2,4,14,15]$. One successful project was involved in the development of bacterial cellulose as a flexible substrate for electronic device. Although bacterial cellulose composite presents the flexibility and transparency and it gains many interests in the further development in electronic industries such as flexible device, the use of bacterial cellulose based materials provided high water absorption ability. Due to the high absorption ability of bacterial cellulose, the development of bacterial cellulose as absorbent materials has been 
currently developed. It was important to note that the properties of interest of bacterial cellulose were involved in extremely hydrophilic feature in nature. As a result, BC will often have poor interface with hydrophobic polymer. However, from the viewpoint of food industry, absorbent materials have been currently developed for the shelf life of food $[16,17]$. To gain higher quality of food product, food packaging has been extensively developed to become active such as high absorption of water and oxygen and antimicrobial properties as well as freshness control. However, due to the versatility of food, the research on active packaging was very dynamic in or der to satisfy on quality of food from production plant, logistics, and transportation as well as consumer. In order to gain the water absorption ability of bacterial cellulose in food packaging, the development of eggshell and bacterial cellulose composite membrane has been extensively developed. It was important to note that eggshell was considered as industrial by-products that have been considered as waste. It was disposed in landfill every year. From the structural point of view, it was important to note that eggshell was considered as a natural bio-based product $[18,19]$. The main component was due to calcium carbonate with very high porosity feature. The research on the use of eggshell as absorbent materials has been therefore improved [20]. Moreover, in order to support the environmentally friendly policy, bio-based materials have been encouraged to develop [21]. To support the use of waste with higher efficiency, modification of eggshell as a composite with bacterial cellulose as absorbent materials should be tailored.

In this research work, we wish to study the development of eggshell and bacterial cellulose composite membrane. Structure and properties of composite membrane were also evaluated. The experiment on absorption ability was therefore determined.

\section{Experimental}

2.1. Materials. Bacterial cellulose was successfully extracted from nata de coco product (chaokoh coconut gel in syrup, Ampol Food Processing Ltd., Nakhon Pathom, Thailand), an indigenous dessert of which main component was reported as bacterial cellulose. Characterizations of bacterial cellulose extracted from nata de coco were carried out in previous work; its characteristics matched those of bacterial cellulose extracted from the culture of Acetobacter xylinum.

Eggshell was collected from canteen, Faculty of Science and Technology, Thammasat University. It was washed with methanol and then dried in an oven at $100^{\circ} \mathrm{C}$ for 24 hours. After that, it was milled and pressed through a sieve with a $25-$ micron mesh. Analytical grade of $\mathrm{NaOH}$ and methanol were purchased from Sigma Aldrich, Thailand, and they were used as received without further purification.

\subsection{Methods}

2.2.1. Extraction and Purification of Bacterial Cellulose. Bacterial cellulose was extracted from nata de coco. The nata de coco gel was first rinsed with distilled water and blended using a laboratory blender. The bacterial cellulose suspension was then treated in $0.1 \mathrm{M} \mathrm{NaOH}$ at $80^{\circ} \mathrm{C}$ for $20 \mathrm{~min}$ to remove any remaining microorganisms, medium component, and soluble polysaccharides. The purified bacterial cellulose was then thoroughly washed with distilled water until $\mathrm{pH}$ was neutral. Additional information has been published in our previous research article $[4,22]$.

2.2.2. Fabrication of Bacterial Cellulose and Eggshell Composite Membrane. To fabricate the composite membrane, the bacterial cellulose sheet was first prepared from bacterial cellulose suspension. The weight ratio between bacterial cellulose and eggshell was controlled as $1: 0.5,1: 1,1: 2$, and $1: 5$, respectively. After that, it was stirred for 3 hours until homogenization was achieved. To fabricate composite membrane, water from suspension was removed through filtration with a Buchner funnel fitted with Polytetrafluoroethylene membrane filter $(0.1 \mathrm{~m}$ mesh and $90 \mathrm{~mm}$ diameter), which was connected to a Buchner flask and a vacuum pump. The filtration was continued until the wet sheet of bacterial cellulose was formed. The wet sheet was then dried between two Polytetrafluoroethylene membranes under the applied pressure of $58 \mathrm{psi}$, following the paper hand sheet formation standard SCAN C 26:76. The sample should be stored in desiccator for water absorption prevention. Characterization techniques such as X-ray diffraction, X-ray fluorescence, Fourier transform infrared, thermogravimetric analysis, scanning electron microscope, and transmission electron microscope were employed to investigate the properties of eggshell and its composite membrane.

\subsubsection{Adsorption Activity of Bacterial Cellulose and Eggshell} Composite Membrane. The adsorption activity of bacterial cellulose and eggshell composite membrane was focused on water and vegetable oil. To determine the absorption capacity of the products, a gravimetric method was applied. An accurately weighed quantity of the sample $(0.5 \mathrm{~g})\left(m_{1}\right)$ was immersed in $100 \mathrm{~mL}$ of distilled water and vegetable oil at room temperature until maximal swelling. The time was operated overnight and then the weight of maximum swelling was detected.

The absorption capacity was calculated as $\mathrm{g} \mathrm{H}_{2} \mathrm{O} / \mathrm{g}$ dry and $g$ vegetable/g dry of composite using the following equation:

$$
\text { Adsorption capacity }(\mathrm{g} / \mathrm{g})=\frac{m_{2}-m_{1}}{m_{1}},
$$

where $m_{1}$ means the weight of dried sample, whereas $m_{2}$ is the weight of tested sample. In all cases, five measurements were performed in order to calculate the statistical average.

\subsection{Characterizations}

2.3.1. X-Ray Diffraction. Eggshell particle was investigated on crystal structure by X-ray diffraction (XRD, Phillips P.W. 1830 diffractometer). It was employed by using nickel-filtered $\mathrm{CuKa}$ radiation. Diffraction patterns were recorded over a range of $10-80$. The scan rate was set for $3^{\circ}$ per min. Prior to 
TABLE 1: Elemental analysis of eggshell.

\begin{tabular}{lcccccc}
\hline Element (wt\%) & $\mathrm{Ca}$ & $\mathrm{O}$ & $\mathrm{Mg}$ & $\mathrm{Al}$ & $\mathrm{S}$ & Others \\
\hline Eggshell & 42.8 & 49.5 & 6.11 & 0.936 & 0.343 & 0.311 \\
$\mathrm{CaCO}_{3}$ (commercial) & 53.4 & 37.6 & 7.74 & 1.24 & 0.018 & 0.002 \\
\hline
\end{tabular}

investigation, the sample should be stored in desiccator for moisture absorption prevention.

2.3.2. Scanning Electron Microscope. Eggshell particle and its composite membrane were investigated on morphological properties by SEM (a JOEL JSM-6301F scanning microscope). The machine was operated at an acceleration voltage of $5 \mathrm{kV}$ to identify the morphological properties of powders. Before investigation, the samples were sputter-coated with $\mathrm{Au}$ to enhance the electrical conductivity.

2.3.3. Thermogravimetric Analysis. Thermal degradation behavior of the eggshell particle and its composite membrane was determined by thermogravimetric analysis (TA-5000 TGA, TA Instruments, DE, USA). Each sample (10 mg) was heated with a heating rate of $10^{\circ} \mathrm{C} / \mathrm{min}$ in nitrogen atmosphere from $30^{\circ} \mathrm{C}$ to $800^{\circ} \mathrm{C}$. The TGA balance flow meter was set at $20 \mathrm{psi} \mathrm{N}_{2}$, while the purge flow meter was adjusted to $20 \mathrm{psi}$ of synthetic air.

2.3.4. X-Ray Fluorescence. XRF (a Phillips 1404 XRF Wavelength Disperse Spectrometer) was used to determine the trace element of sample. It was equipped with an array of five analyzing crystals and fitted with a Rh X-ray tube target. A vacuum was used as the medium of analyses to avoid interaction of $\mathrm{X}$-rays with air particle. $1 \mathrm{~g}$ of sample was mixed with $6 \mathrm{~g}$ of $\mathrm{H}_{3} \mathrm{BO}_{3}$ and consequently pressed under 10 tons of force.

2.3.5. Fourier Transforms Infrared. FTIR was performed on a Bruker Vector 22 mid-IR spectroscopy (Bruker, Germany), All FTIR absorption spectra were recorded over 4000$400 \mathrm{~cm}^{-1}$ wavenumbers region at a resolution of $8 \mathrm{~cm}^{-1}$ with 1024 scans using a deuterated triglycine sulfate (DTGS) detector. A straight line between two lowest points in the respective spectra region was chosen as a baseline. Potassium bromide $(\mathrm{KBr})$ acting as a nonabsorbing medium was mixed with a solid sample $(0.3-0.5 \mathrm{wt} \%)$ by an agate mortar and pestle to prepare a pellet specimen.

2.3.6. Tensile Test. The tensile tests were conducted in accordance to the ISO Standard number ISO 527:1996. The sample was cut with a Zwick cutter into dog-bone specimen type 5A. The samples had the overall length and the gauge length of 75 and $20 \mathrm{~mm}$, respectively. The initial distance between grips was $50 \mathrm{~mm}$ and its width at the grip end was $12.5 \mathrm{~mm}$. The width at the narrowest part was $4 \mathrm{~mm}$ and the thickness was $0.3-0.5 \mathrm{~mm}$. The testing speed was $1 \mathrm{~mm} / \mathrm{min}$. The specimens were preconditioned at $20^{\circ} \mathrm{C}$ in $54 \%$ relative humidity in a desiccator containing a saturated solution of $\mathrm{Mg}\left(\mathrm{NO}_{3}\right)_{2}$ for at least $48 \mathrm{~h}$ prior to testing. The tensile test was conducted using

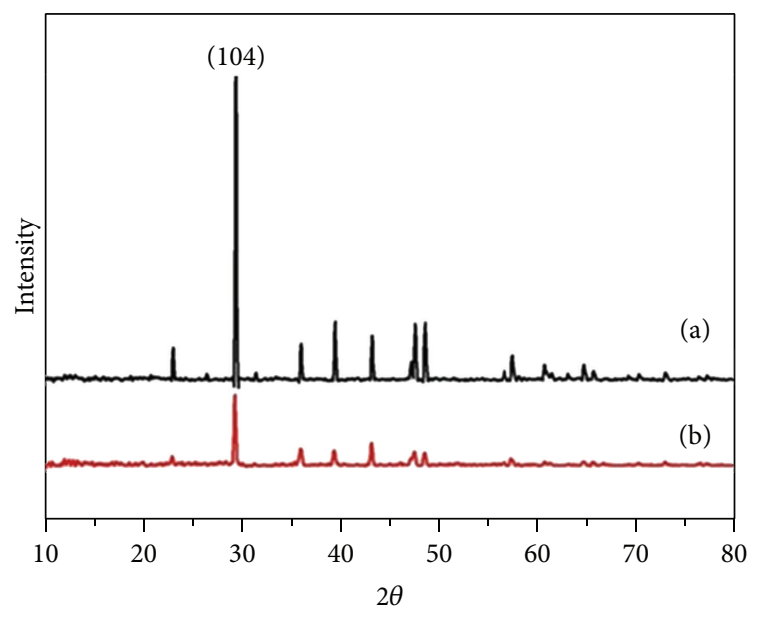

FIGURE 1: X-ray diffraction pattern of (a) eggshell and (b) commercial calcium carbonate.

Instron universal material testing machine (Instron 4502, Instron Corporation, MA, USA) equipped with a $1 \mathrm{kN}$ load cell. At least 10 specimens were tested per sample to obtain a statistical average.

\section{Results and Discussion}

3.1. Characterization of Eggshell from Renewable Resource. Table 1 exhibits element analysis of eggshell. It was important to note that chemical composition of eggshell was associated with $\mathrm{CaCO}_{3}$. The main component was focused on calcium and oxygen and it was remarkable to note that it can be considered as effective resource for calcium oxide. However, the variation in the amount of element was still varied due to feed of the hen and it was contaminated by the inner membrane of egg. To use eggshell with higher efficiency, the controllability on elemental analysis should be performed.

$\mathrm{X}$-ray diffraction pattern of eggshell was investigated and the commercial $\mathrm{CaCO}_{3}$ was provided for comparison. Figure 1 exhibits the X-ray diffraction pattern. It was remarkable to note that there is no phase of impurities. The existence of peak was involved in $\mathrm{CaCO}_{3}$. The characteristic peak was associated with JCPDS number 47-1743. The result presented the existence of $\mathrm{CaCO}_{3}$ derived from eggshell waste. Furthermore, it was important to note that the preferential orientation was determined using a texture coefficient $(h k l)$. The full width at half maximum (FWHM) of the $100 \%$ intensity (104) peak at $2 \theta=29.5$ was determined for all calcium carbonate derived from eggshell. It illustrated that the highest value was in the (104) plane for the sample, which indicated that crystal orientation is uniform in $x$ - and $z$ orientation. The crystal size was estimated by the Scherrer 


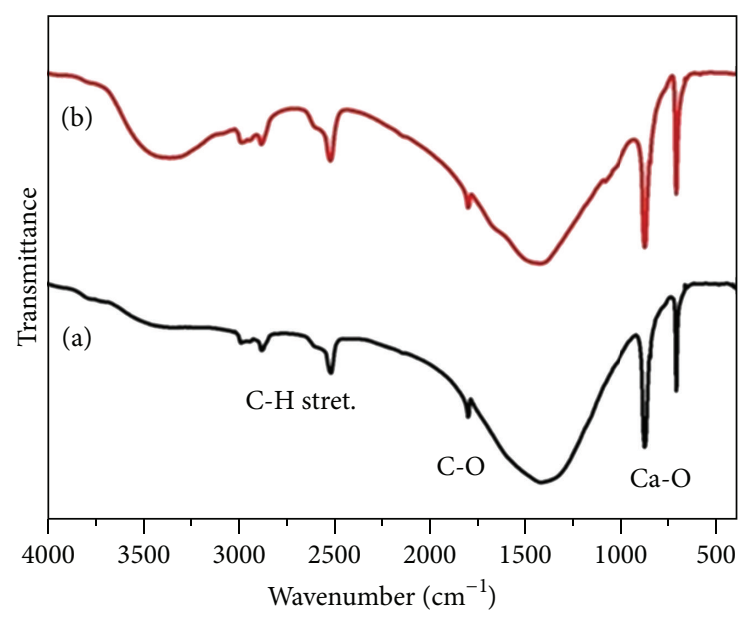

FIGURE 2: FTIR pattern of (a) eggshell and (b) commercial calcium carbonate.

formula: $D=K \lambda / \beta \cos \theta$, where $D$ is crystallite size, $K$ is a constant of $0.9, \lambda$ is the $\mathrm{X}$-ray wavelength, $\beta$ is full width at half maximum (FWHM), and $\theta$ is the diffraction peak. The (104) peak was used to estimate the crystal and it was found to be $50-70 \mathrm{~nm}$.

Figure 2 exhibits FTIR pattern of eggshell particle and commercial $\mathrm{CaCO}_{3}$ was provided for comparison. Both results presented the similar feature of pattern. The intense band was observed at $3600 \mathrm{~cm}^{-1}$ due to the vibration of the $\mathrm{OH}$ group attached to $\mathrm{Ca}^{2+}$. It can be implied that surface of eggshell exhibited hydrophilic properties. In order to prevent this concern, eggshell should be stored in desiccator. Moreover, the characteristic peak position at $1500 \mathrm{~cm}^{-1}$ was due to $\mathrm{C}-\mathrm{O}$ stretching. The remaining part of carbonate still existed. The wavenumber at $700 \mathrm{~cm}^{-1}$ belonged to $\mathrm{Ca}-\mathrm{O}$ stretching. It can be noted that the composition of eggshell was referred to calcium carbonate. This discussion was strongly associated with XRD experiment.

In the case of eggshell particle, it was suspended in water solution. It was important to note that most of the particles were precipitated within a minute leaving a clear aqueous supernatant immediately after the preparation. From the fundamental point of view, due to the nature of eggshell, it presented the hydrophilic feature on surface. To determine the particle size of eggshell, the good distribution of eggshell particle should be controlled. This indicated that eggshell particle was facile to aggregate in an aqueous suspension, suggesting that ultrasonic process should be performed. From the theoretical point of view, it was important to note that eggshell particle can be stabilized by two main forces. The one was focused on van der Waals' interactions and the other one was focused on electrostatic repulsive force. When the attraction force is less than repulsive force, the particle was dispersed, and if the attraction force exceeds the repulsive force, the particle tended to form aggregates. It was important to note that the determination of particle of eggshell and good distribution should be performed in order to prevent any error from measurement.

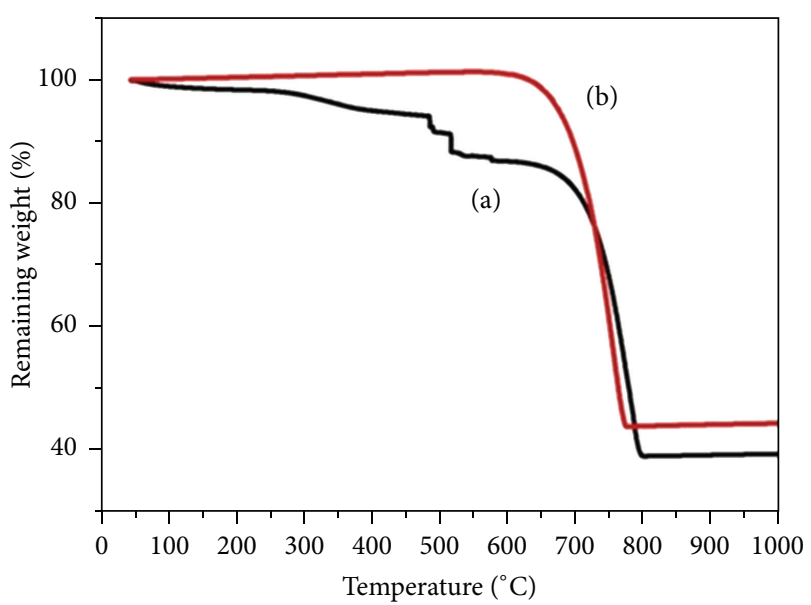

FIGURE 3: Thermogravimetric analysis of (a) eggshell and (b) commercial $\mathrm{CaCO}_{3}$.

Furthermore, the stability of eggshell particle was therefore investigated. Thermogravimetric analysis was conducted. The analysis was used to determine the weight loss as a function of elevated temperature. Figure 3 exhibits the thermal decomposition of eggshell particle and commercial $\mathrm{CaCO}_{3}$ was provided for comparison. It can be noted that when the thermal temperature reached $400^{\circ} \mathrm{C}$, small weight loss was observed due to water absorption on eggshell particle. This indicated that the surface of eggshell exhibited hydrophilic feature. Moreover, decomposition can be categorized into three different regions. Within the temperature region of $400-800^{\circ} \mathrm{C}$, the large region of weight loss was therefore observed. This was due to the change in structure of $\mathrm{CaCO}_{3}$ to calcium oxide ceramic. From the theoretical point of view, $\mathrm{CaCO}_{3}$ can be changed to calcium oxide when high temperature was applied. This discussion was strongly associated with X-ray diffraction experiment. Moreover, with the increment on temperature in the range of $800-1000^{\circ} \mathrm{C}$, no weight loss was therefore observed due to that, suggesting that the decomposition was completely performed.

\subsection{Characterization of Eggshell and Bacterial Cellulose Composite Membrane}

3.2.1. Characterization of Bacterial Cellulose and Eggshell Composite Membrane. Eggshell and bacterial cellulose composite membrane was successfully prepared. It was important to note that the weight ratio between bacterial cellulose and eggshell was controlled as 1:0.5, 1:1, 1:2, and 1:5, respectively. Figure 4 exhibits the thermal decomposition of bacterial cellulose and eggshell composite membrane. The decomposition temperature can be categorized into three different regions, similar to neat eggshell waste. From room temperature to $300^{\circ} \mathrm{C}$, small weight loss can be observed due to effect of water absorption. With the temperature range from $300-700^{\circ} \mathrm{C}$, the large decomposition was therefore observed due to decomposition of bacterial cellulose and the calcium carbonate which was considered as the main 
TABLE 2: Mechanical properties of bacterial cellulose and eggshell composite membrane.

\begin{tabular}{lccc}
\hline Composites & Young's modulus (MPa) & Tensile strength (MPa) & Elongation (\%) \\
\hline Neat bacterial cellulose sheet & $4.16 \pm 0.003$ & $13.2 \pm 0.005$ & $3.17 \pm 0.005$ \\
Bacterial cellulose and eggshell $(1: 0.5 \mathrm{wt} \%)$ & $3.89 \pm 0.001$ & $7.05 \pm 0.001$ & $1.81 \pm 0.003$ \\
Bacterial cellulose and eggshell $(1: 1 \mathrm{wt} \%)$ & $0.40 \pm 0.002$ & $2.53 \pm 0.002$ & $6.29 \pm 0.003$ \\
Bacterial cellulose and eggshell $(1: 2 \mathrm{wt} \%)$ & $0.42 \pm 0.001$ & $1.47 \pm 0.002$ & $3.50 \pm 0.001$ \\
Bacterial cellulose and eggshell $(1: 5 \mathrm{wt} \%)$ & $0.12 \pm 0.002$ & $0.78 \pm 0.001$ & $6.37 \pm 0.002$ \\
\hline
\end{tabular}

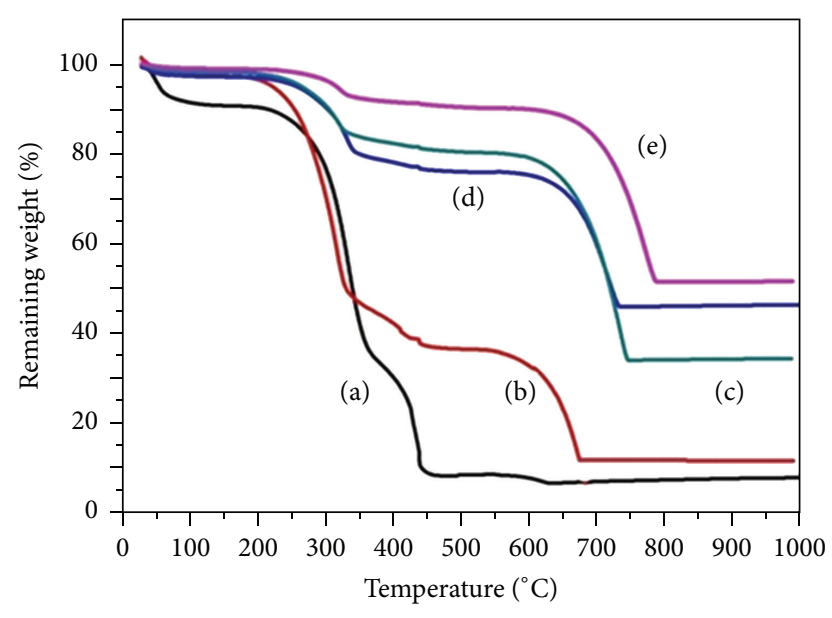

FIGURE 4: Thermal decomposition of eggshell and bacterial cellulose composite membrane. (a) Neat bacterial cellulose. (b) $1: 0.5$ weight ratio of bacterial cellulose and eggshell. (c) $1: 1$ weight ratio of bacterial cellulose and eggshell. (d) 1:2 weight ratio of bacterial cellulose and eggshell. (e) 1:5 weight ratio of bacterial cellulose and eggshell.

component of eggshell. Moreover, in the region of 700$1000^{\circ} \mathrm{C}$, high stability of weight loss was detected; there is no change due to weight loss. The residual was due to char from bacterial cellulose and calcium oxide due to decomposition of eggshell. Also, the amount of residual was very high, similar to the amount of eggshell in bacterial cellulose composite.

Mechanical properties of bacterial cellulose and eggshell composite membrane were investigated. Young's modulus, tensile strength, and elongation were determined. Table 2 exhibits the mechanical properties of eggshell composite membrane. The mechanical properties of neat bacterial cellulose were provided for comparison. Young's modulus and tensile strength were decreased with the increment of eggshell. Due to the difference in physical properties of bacterial cellulose and eggshell particle, eggshell particle was embedded into bacterial cellulose network. From the structural point of view, the structure of bacterial cellulose presented nanonetwork or a three-dimensional network structure of fiber with air interstices in between; when the tensile stress was applied to the bacterial cellulose, the stress would be transferred through the fiber network. However, in all cases of bacterial cellulose and eggshell composite membrane, although significant enhancement in adsorption ability was therefore observed, the inferior mechanical properties were subsequently detected, suggesting that the optimization between bacterial cellulose and eggshell particle should be controlled in order to tailor the excellent performance of adsorption and mechanical properties. To gain the flexibility of composite membrane, the correlation of bacterial cellulose and eggshell should be incorporated into polymer matrix and it can be further facilitated for use in many packaging industries. On the other hand, it was remarkable to note that mechanical properties were slightly decreased when amount of eggshell particle was filled. The reason was due to the fact that the existence of eggshell particle did not provide the strong chemical bonding with bacterial cellulose such as ionic and covalent bonds. It may provide only physical bonding such as van der Waals' force. The increase in the loading of biomicroparticle in the resulting biomicrocomposites will begin to experience more and more particleto-particle interaction rather than the intended particle-topolymer interaction. Particle-to-particle interaction will lead to particle agglomerations and poor mechanical properties. Composite was therefore provided less amount of mechanical properties compared to neat bacterial cellulose.

Figure 5 exhibits the morphological properties of eggshell and bacterial cellulose composite membrane. The neat of bacterial cellulose sheet was provided for comparison. In composite structure, the existence of eggshell powder was filled in the network of bacterial cellulose. From the structural point of view, the structure of bacterial cellulose consisted of fibril network. The air-space existed in between. It was remarkable to note that as exhibited in many literatures bacterial cellulose network provided the excellent specific surface area and porosity. The existence of eggshell powder was filled into bacterial cellulose network. It can be rendered on the increment of specific surface area. The existence of eggshell in bacterial cellulose network can be also offered the significant enhancement of thermal stability and adsorption ability.

\subsubsection{Adsorption Activity of Bacterial Cellulose and Eggshell} Composite Membrane. To employ bacterial cellulose and eggshell composite membrane in packaging industries, the development of absorbent materials has been researched. In food industry, packaging has been extensively designed for high adsorption ability for water and vegetable. Since both of them were enormously employed in food processing, to design the appropriate active packaging for high adsorption ability of water and vegetable oil was one of the important key factors in order to maintain the quality and shelf life of food. From the structural point of view, the properties of bacterial cellulose and eggshell particle exhibited high specific surface 


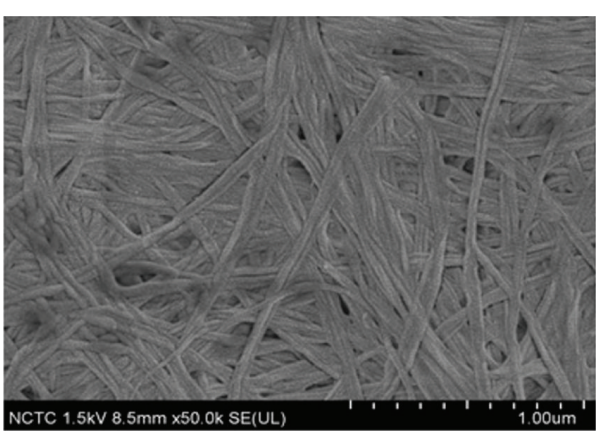

(a)

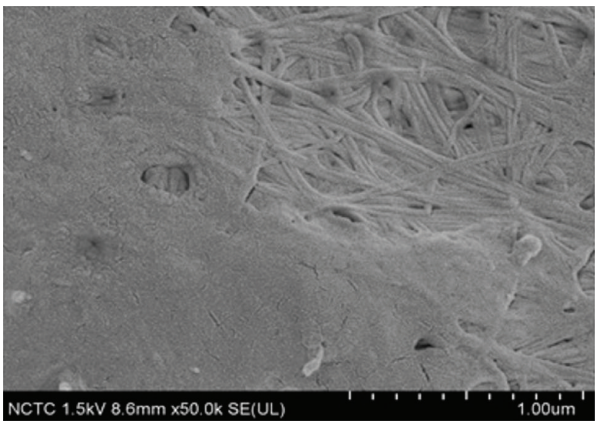

(c)

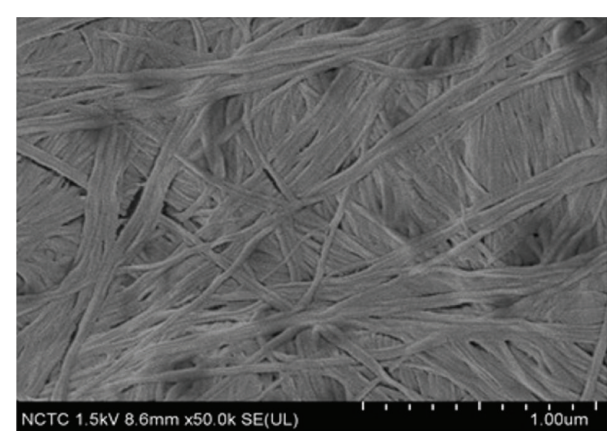

(b)

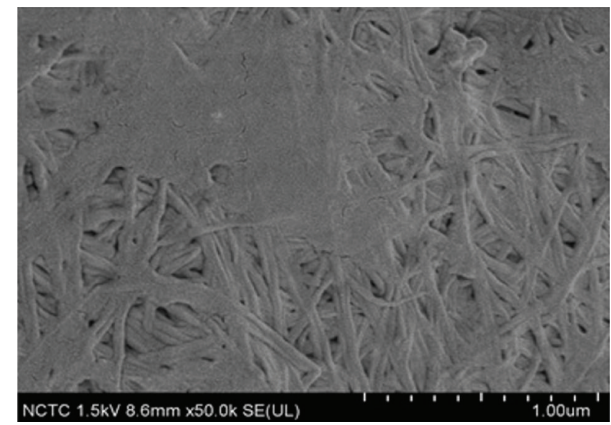

(d)

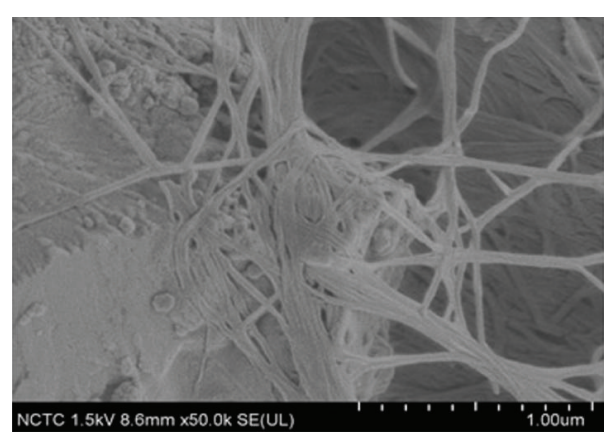

(e)

FIGURE 5: Morphological properties of eggshell and bacterial cellulose composite membrane (a) neat bacterial cellulose. (b) $1: 0.5$ weight ratio of bacterial cellulose and eggshell. (c) $1: 1$ weight ratio of bacterial cellulose and eggshell. (d) 1:2 weight ratio of bacterial cellulose and eggshell. (e) 1:5 weight ratio of bacterial cellulose and eggshell.

area. It was therefore considered as absorbent materials. Bacterial cellulose was considered as network-like structure of fibrils containing hydroxyl group along glucose unit. The repulsion force was enrolled and it provided the free space along bacterial cellulose network. Hydrogen formation can occur from the reaction of glucose unit with water and vegetable oil. It involved intermolecular and intramolecular force in between. High adsorption ability was therefore observed. This discussion was strongly associated with vegetable oil. The hydroxyl group from bacterial cellulose network and polyol group from vegetable oil were therefore involved. A significant effort on bonding formation was employed to consider on adsorption ability in water and vegetable oil for bacterial cellulose. The objective is to investigate the feasibility of high water and vegetable oil absorbency and the strength of composite. The role of water and vegetable oil can be cross-linked with the hydroxyl position of bacterial cellulose. Swelling aspect was subsequently detected. Table 3 and Figure 6 exhibit the water adsorption capacity and vegetable oil adsorption capacity of bacterial cellulose and eggshell composite membrane. Moreover, it can be remarkable to note that the ability of adsorption increased with respect to amount of eggshell particle. The eggshell particle existed in the network of bacterial cellulose as investigated by SEM analysis. Eggshell particle shows high specific surface area and porosity. It therefore provided high adsorption ability. Another reason was involved in calcium atom from eggshell particle; it can be dissolved in water and 
TABLE 3: Water adsorption capacity and vegetable oil adsorption capacity of bacterial cellulose and eggshell composite membrane.

\begin{tabular}{lcc}
\hline Composites & Water adsorption capacity $(\mathrm{g} / \mathrm{g})$ & Vegetable oil adsorption capacity $(\mathrm{g} / \mathrm{g})$ \\
\hline Neat bacterial cellulose sheet & $0.0658 \pm 0.003$ & $0.2631 \pm 0.013$ \\
Bacterial cellulose and eggshell $(1: 0.5 \mathrm{wt} \%)$ & $0.4588 \pm 0.023$ & $0.7195 \pm 0.036$ \\
Bacterial cellulose and eggshell $(1: 1 \mathrm{wt} \%)$ & $0.4849 \pm 0.024$ & $0.7732 \pm 0.039$ \\
Bacterial cellulose and eggshell $(1: 2 \mathrm{wt} \%)$ & $0.6479 \pm 0.032$ & $1.3285 \pm 0.066$ \\
Bacterial cellulose and eggshell $(1: 5 \mathrm{wt} \%)$ & $1.0501 \pm 0.052$ & $1.5275 \pm 0.076$ \\
\hline
\end{tabular}

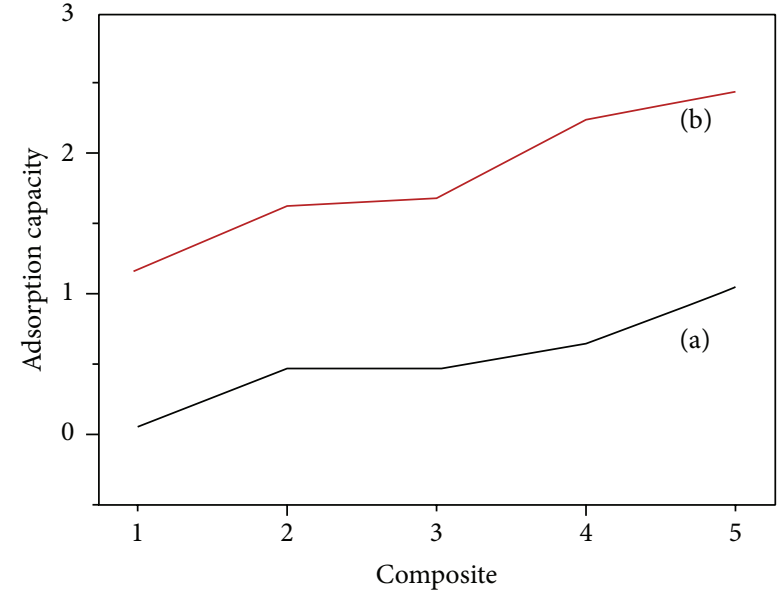

FIGURE 6: Adsorption capacity of bacterial cellulose and eggshell composite membrane. (a) Water adsorption. (b) Vegetable oil adsorption. (1) Neat bacterial cellulose. (2) 1:0.5 weight ratio of bacterial cellulose and eggshell. (3) 1:1 weight ratio of bacterial cellulose and eggshell. (4) 1:2 weight ratio of bacterial cellulose and eggshell. (5) 1:5 weight ratio of bacterial cellulose and eggshell.

subsequently formed the chemical bond between bacterial cellulose. It provided an attracted force to water and vegetable oil molecule. However, it was controversial that the free space in bacterial cellulose network was still less due to the existence of eggshell and the adsorption ability over water and vegetable oil molecule might be consequently less. Due to the cuticle composition in eggshell, it still had the porosity. The water and vegetable oil were still adsorbed in bacterial cellulose and eggshell waste composite. It was suggested that composite provided significant ability to adsorption of water and vegetable oil molecule. It exhibited the excellent performance and qualified as the excellent candidate for adsorbent material in food packaging.

\section{Conclusion}

Bacterial cellulose and eggshell composite membrane was successfully developed. Eggshell particle was mixed with bacterial cellulose suspension and it was casted as a film composite. Characterization on eggshell waste can confirm that the main composition of eggshell is referred $\mathrm{CaCO}_{3}$ with high porosity. The development of bacterial cellulose and eggshell composite membrane was preliminary tested on water and vegetable oil absorption ability. It exhibited the potential to use eggshell as absorbent materials in active packaging.

\section{Competing Interests}

The authors declare that there are no competing interests regarding the publication of this paper.

\section{Acknowledgments}

The authors gratefully acknowledge the financial support provided by Thammasat University under the TU Research Scholar. The Contract no. is 11/2559.

\section{References}

[1] O. Faruk, A. K. Bledzki, H.-P. Fink, and M. Sain, "Biocomposites reinforced with natural fibers: 2000-2010," Progress in Polymer Science, vol. 37, no. 11, pp. 1552-1596, 2012.

[2] S. Ummartyotin and H. Manuspiya, "A critical review on cellulose: from fundamental to an approach on sensor technology," Renewable and Sustainable Energy Reviews, vol. 41, pp. 402-412, 2015.

[3] P. S. Guru and S. Dash, "Sorption on eggshell waste-a review on ultrastructure, biomineralization and other applications," Advances in Colloid and Interface Science, vol. 209, pp. 49-67, 2014.

[4] S. Ummartyotin, J. Juntaro, M. Sain, and H. Manuspiya, "Development of transparent bacterial cellulose nanocomposite film as substrate for flexible organic light emitting diode (OLED) display," Industrial Crops and Products, vol. 35, no. 1, pp. 92-97, 2012.

[5] M. Z. Elsabee and E. S. Abdou, "Chitosan based edible films and coatings: a review," Materials Science and Engineering C, vol. 33, no. 4, pp. 1819-1841, 2013.

[6] J. Liu, X. Zhan, J. Wan, Y. Wang, and C. Wang, "Review for carrageenan-based pharmaceutical biomaterials: favourable physical features versus adverse biological effects," Carbohydrate Polymers, vol. 121, pp. 27-36, 2015.

[7] N. Lavoine, I. Desloges, A. Dufresne, and J. Bras, "Microfibrillated cellulose-its barrier properties and applications in cellulosic materials: a review," Carbohydrate Polymers, vol. 90, no. 2, pp. 735-764, 2012.

[8] H. P. S. Abdul Khalil, A. H. Bhat, and A. F. Ireana Yusra, "Green composites from sustainable cellulose nanofibrils: a review," Carbohydrate Polymers, vol. 87, no. 2, pp. 963-979, 2012.

[9] A. Carlmark, E. Larsson, and E. Malmström, "Grafting of cellulose by ring-opening polymerisation-a review," European Polymer Journal, vol. 48, no. 10, pp. 1646-1659, 2012. 
[10] C. Wu, "Production and characterization of optically transparent nanocomposite film," in Faculty of Forestry, University of Toronto, Toronto, Canada, 2010.

[11] K.-Y. Lee, J. J. Blaker, and A. Bismarck, "Surface functionalisation of bacterial cellulose as the route to produce green polylactide nanocomposites with improved properties," Composites Science and Technology, vol. 69, no. 15-16, pp. 2724-2733, 2009.

[12] K.-Y. Lee, P. Bharadia, J. J. Blaker, and A. Bismarck, "Short sisal fibre reinforced bacterial cellulose polylactide nanocomposites using hairy sisal fibres as reinforcement," Composites Part A: Applied Science and Manufacturing, vol. 43, no. 11, pp. 20652074, 2012.

[13] K.-Y. Lee, K. K. C. Ho, K. Schlufter, and A. Bismarck, "Hierarchical composites reinforced with robust short sisal fibre preforms utilising bacterial cellulose as binder," Composites Science and Technology, vol. 72, no. 13, pp. 1479-1486, 2012.

[14] S. Ummartyotin, J. Juntaro, M. Sain, and H. Manuspiya, "SiO barrier technology for bacterial cellulose nanocomposite flexible displays," Carbohydrate Polymers, vol. 86, no. 1, pp. 337342, 2011.

[15] S. Ummartyotin and H. Manuspiya, "An overview of feasibilities and challenge of conductive cellulose for rechargeable lithium based battery," Renewable and Sustainable Energy Reviews, vol. 50, pp. 204-213, 2015.

[16] C. E. Realini and B. Marcos, "Active and intelligent packaging systems for a modern society," Meat Science, vol. 98, no. 3, pp. 404-419, 2014.

[17] L. Barbosa-Pereira, I. Angulo, J. M. Lagarón, P. Paseiro-Losada, and J. M. Cruz, "Development of new active packaging films containing bioactive nanocomposites," Innovative Food Science \& Emerging Technologies, vol. 26, pp. 310-318, 2014.

[18] H. Yu, Q. Tang, J. Wu et al., "Using eggshell membrane as a separator in supercapacitor," Journal of Power Sources, vol. 206, pp. 463-468, 2012.

[19] P. Suppakul, K. Jutakorn, and Y. Bangchokedee, "Efficacy of cellulose-based coating on enhancing the shelf life of fresh eggs," Journal of Food Engineering, vol. 98, no. 2, pp. 207-213, 2010.

[20] D. Podstawczyk, A. Witek-Krowiak, K. Chojnacka, and Z. Sadowski, "Biosorption of malachite green by eggshells: mechanism identification and process optimization," Bioresource Technology, vol. 160, pp. 161-165, 2014.

[21] T. Boronat, V. Fombuena, D. Garcia-Sanoguera, L. SanchezNacher, and R. Balart, "Development of a biocomposite based on green polyethylene biopolymer and eggshell," Materials and Design, vol. 68, pp. 177-185, 2015.

[22] K. O-Rak, E. Phakdeepataraphan, N. Bunnak, S. Ummartyotin, M. Sain, and H. Manuspiya, "Development of bacterial cellulose and poly(vinylidene fluoride) binary blend system: structure and properties," Chemical Engineering Journal, vol. 237, pp. 396402, 2014 

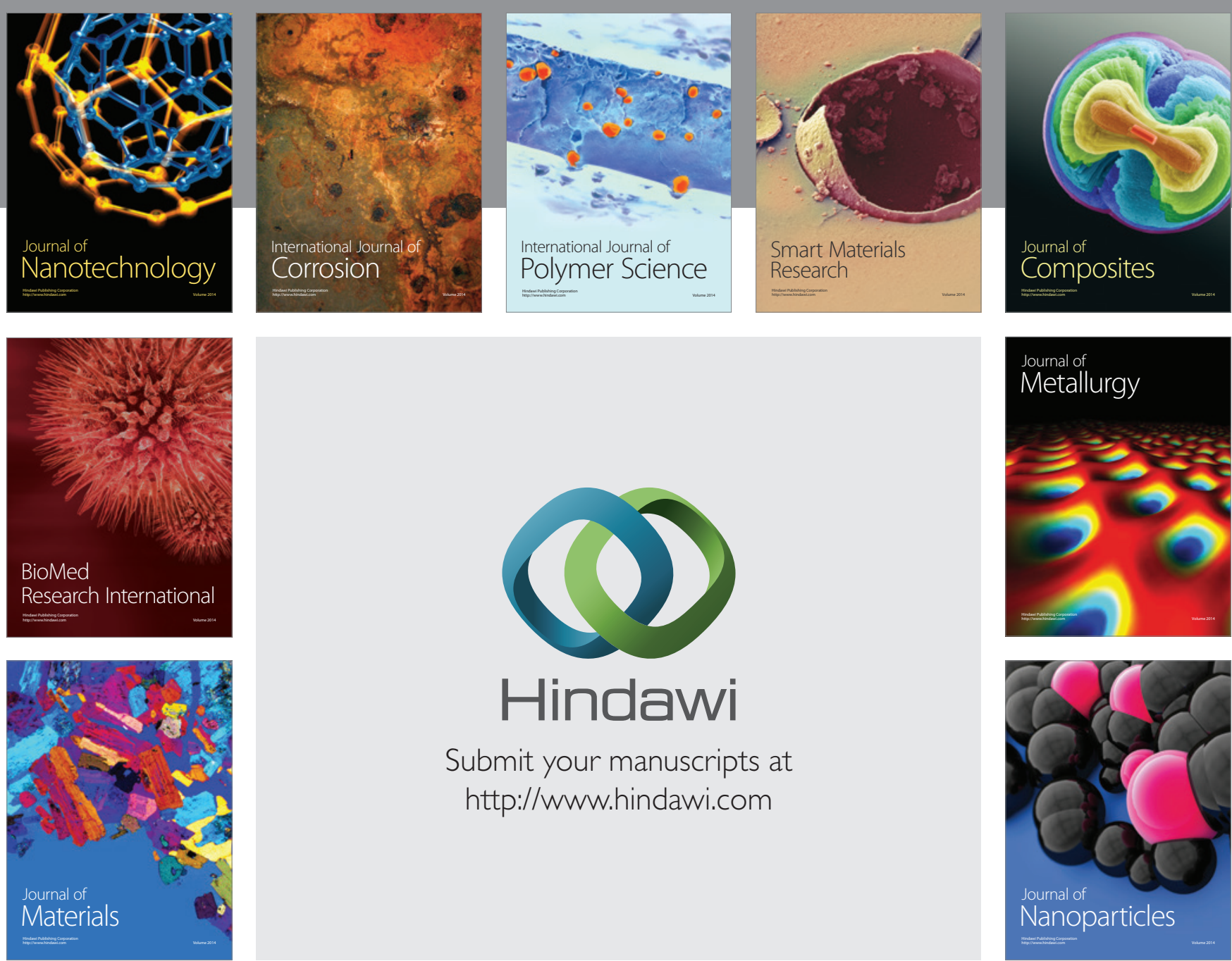

\section{Hindawi}

Submit your manuscripts at

http://www.hindawi.com

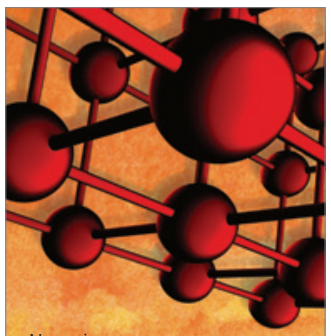

Materials Science and Engineering
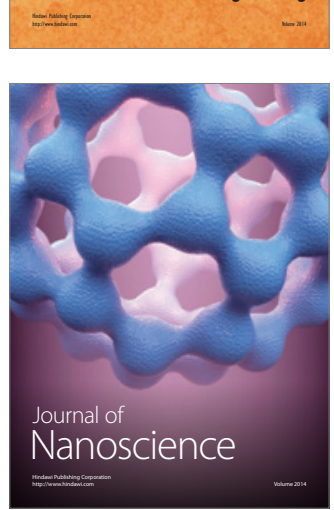
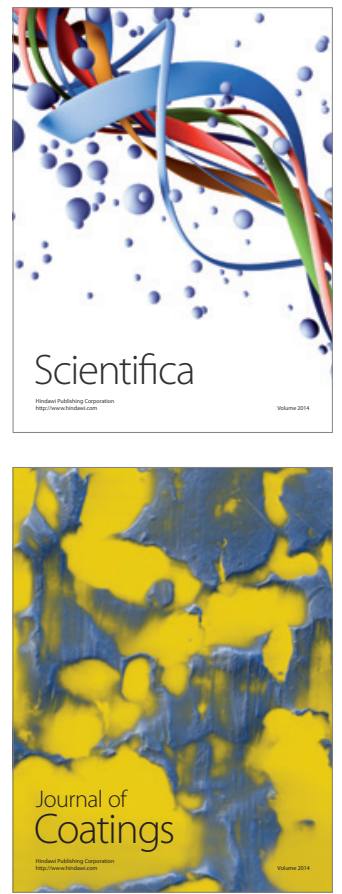
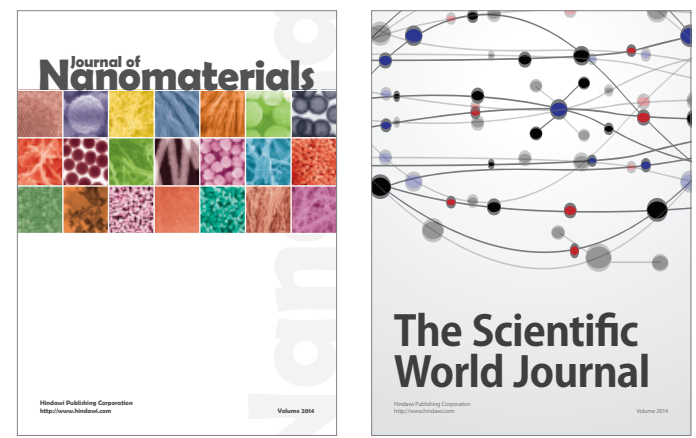

The Scientific World Journal
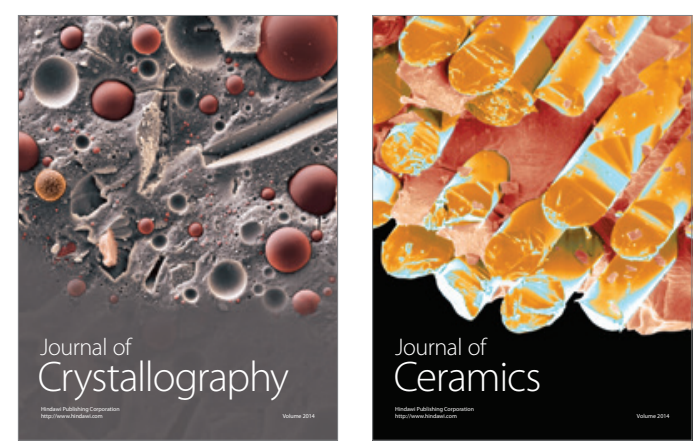
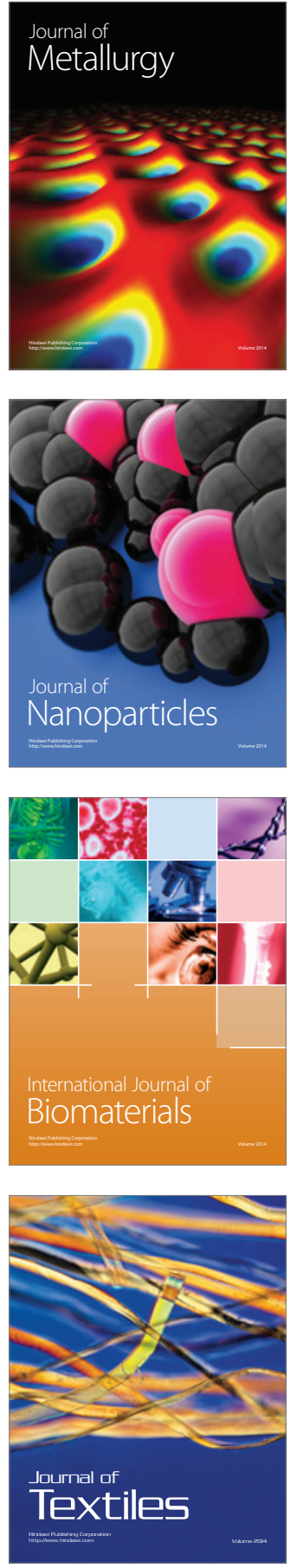